\title{
РОЛЬ НАУКИ В МОДЕРНІЗАЦІЇ УКРАЇНСЬКОГО СУСПІЛЬСТВА
}

Метою статті є дослідження сутності, тенези та можливостей України як нової незалежної держави в сучасному глобалізованому світі. Для иього застосовувалися загальнонаукові та спеціальні методи дослідження. Визначено, щзо наша держава перебуває сьогодні в особливому стані. Лише правильно визначивши цей стан, ми зможемо вийти на шлях сочіального прогресу. Обгрунтовується, щу без допомоги наукових досліджень зробити ие практично неможливо. У статті уточнено зміст окремих понять, набули подальшого розвитку погляди щуодо їхнього застосування в модернізаційному прочесі. Сучасна російсько-українська війни та прагнення Украӥни вступити до НАТО висувають нові вимоги до можливостей українського суспільства. Зазначене потребує подальших наукових досліджень, пов'язаних з модернізацією украӥнського суспільства загалом $i$ реформуванням освітнього та наукового простору України зокрема.

Ключові слова: наука; постколоніальні держави; украӥнське суспільство; модернізачія; військова реформа; наџіональна безпека; російсько-украйнська війна.

Постановка проблеми. Сучасна Україна переживає складний та відповідальний етап свого розвитку, який обумовлюються наростанням кризових явищ в усіх сферах суспільства, виникненням нових загроз і викликів національній безпеці нашої держави, на які необхідно давати рішучі відповіді. Серед багатьох проблем, породжених динамізмом сучасної епохи, особливе місце посідає російська експансіоністська політика, яка кардинально змінила військово-політичну обстановку у світі. Російська Федерація вперше після Другої світової війни поставила під сумнів усталеність кордонів між державами, здійснивши анексію Криму та окупацію східних теренів України. Відтак внутрішні та зовнішні чинники свідчать про існування загроз, які можуть негативно вплинути на збереження суверенітету нашої держави. У цьому контексті важливе місце належить науці, яка зобов'язана правильно визначити стан, у якому перебуває сучасне українське суспільство, вказати головні напрями його модернізації, що сприятимуть соціальному прогресу.

Аналіз останніх досліджень і публікацій. Зазначені чинники вимагають нових підходів до напрямів реформування військової сфери українського суспільства, а це, у свою чергу, неможливе без його глибокої модернізації. Зрозуміло, що i перше, i друге вимагають детального теоретичного опрацювання. Проте, на жаль, як зазначає М. Михальченко, «в Україні вогник теоретичної думки в сфері суспільних наук ледь-ледь жевріє» [1, с. 8]. I це в той час, коли українське суспільство потребує науково обгрунтованого підходу до реформування усіх ланок суспільного життя, визначення нових стратегічних пріоритетів щодо російсько-української війни. Саме тому важливого значення 
набувають дослідження напрямів модернізації українського суспільства i, зокрема, реформування та розбудови його військової сфери. Таких праць, на думку М. Михальченка, надзвичайно мало [1, с. 8], а ті, що є зазвичай неадекватно відображають сутнісні характеристики українського суспільства та процеси, які в ньому і $з$ ним відбуваються.

Ще далі у своїй характеристиці сучасної України йде О. Костенко, який у статті 3 промовистою назвою «Антинаукова Україна» зазначає, що наша держава «перебуває сьогодні в особливому стані. Лише правильно визначивши цей стан, ми можемо вийти на шлях соціального прогресу. Усі ті негаразди, які ми маємо нині, слід визначити як Велику Соціальну Драму. I вийти із цього драматичного стану можна лише виявивши і усунувши його коріння» [2]. На думку дослідника, «однією 3 причин невдач у здійсненні політичних, економічних, правових, моральних та інших реформ в Україні $\epsilon$ їхній антинауковий характер, внаслідок чого вони стали проявом реформаторського волюнтаризму та утопізму. Прогресивні вчені усього світу все більше переконуються у тому, що політика, як вважав А. Ейнштейн, «набагато складніша за фізику», тому сьогодні політик-реформатор, який не спирається на соціальні науки, нагадує вершника без голови» [2].

Підбиваючи підсумки, О. Костенко висновує, що в «Україні має місце разючий науковий нігілізм, а також політичне, економічне, правове, моральне невігластво. Тому про сучасну Україну можна образно сказати: «антинаукова країна». На цьому грунті процвітають різноманітні соціальні химери, популізм, псевдолібералізм, псевдодемократія, зловживання демократичними інструментами, зловживання законодавством та судовою владою, псевдоморальність, войовнича бездуховність тощо» [2]. Подолати зазначені «соціальні хвороби», на його думку, можна лише за допомогою «соціальних (i гуманітарних) наук» [2].

Особливе місце в аналізі процесів, які відбуваються в нових незалежних державах, належить сучасному німецькому філософу В. Гьосле. На його думку, необхідною теоретичною передумовою дослідження країн, що розвиваються, $\epsilon$ філософська рефлексія щодо їхньої сутності та генези. Як зазначалося вище, для сучасної України вирішення цієї проблеми є особливо актуальним, оскільки вона перебуває на складному етапі свого існування, а військова сфера українського суспільства переживає неоднозначний процес будівництва та реформування за умов триваючої російської агресії. Для того, щоб зрозуміти та усвідомити сутність явищ, пов'язаних з цією «складною реальністю», якою, на думку В. Гьосле, є «країни, що розвиваються», необхідно розглянути зміст цього поняття [3, с. 145-146].

Зважаючи на вищезазначене, метою статті $\epsilon$ визначення статусу українського суспільства виходячи 3 досвіду нових незалежних держав; уточнення змісту низки понять, які стосуються країн, що розвиваються; обгрунтування шляхів та напрямів модернізації українського суспільства.

Методи дослідження. Застосування загальнонаукових та спеціальних методів при дослідженні нових незалежних держав i зокрема українського 
суспільства зумовлене специфікою цього складного соціального явища, яким $є$ зазначені країни.

Виклад основного матеріалу. Спроби усвідомлення сутності українського суспільства в нашій державі здійснюються від моменту проголошення іï незалежності. Проте однозначних відповідей на виклики, які постають перед Україною, досі не сформульовано. Це сталося внаслідок того, що, по-перше, українським науковцям властиві вади загального характеру, на які наголошує В. Гьосле [3, с. 145-146]. А по-друге, як зазначає О. Костенко, в нашій державі панує науковий нігілізм. Відтак помилка українських науковців полягає в тому, що характеризуючи Україну, вони використовують ознаки, які стосуються ii опосередковано. А це призводить до розробки хибних рекомендацій щодо етапів та шляхів модернізації українського суспільства, а також до запозичення досвіду країн, який на сучасному етапі практично неможливо реалізувати в Україні. Наприклад, якщо застосовувати до української держави таку ознаку, як «посттоталітарна», то їі можна ставити в один шерег 3 Іспанією, Італією, Німеччиною, Японією та ін. Якщо ж використовувати «посткомуністичну», «постсоціалістичну», «пострадянську» ознаки, то Україну можна порівнювати з Російською Федерацією, Сербією, Чехією або Угорщиною.

Вочевидь, в обох випадках порівняння є некоректними, оскільки до 1991 р. Україна була складовою частиною держави, яка характеризувалася певною сукупністю ознак - таких як «радянська», «комуністична», «соціалістична», «тоталітарна» тощо і, будучи імперією, мала статус метрополії стосовно України. Виходячи 3 того, що ці ознаки формувалися за межами України i

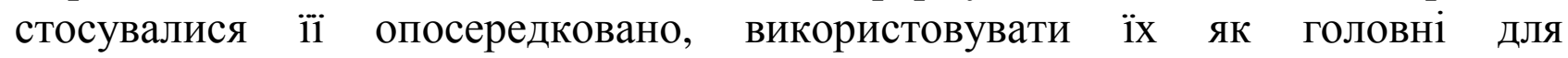
характеристики минулого держави, яка на той час не мала суверенітету, на нашу думку, недоречно. Наприклад, якби колишні колонії окремих країн західної демократії, тобто переважно азіатські та африканські держави, називали себе «постдемократичними», це викликало б неприхований подив.

Відтак після досягнення політичної незалежності ознаки, притаманні метрополіям, не можуть автоматично переходити до характеристики новостворених країн. Тут на перший план повинні вийти ознаки, які б адекватно відображала статус держави (суспільства) як до, так i після проголошення незалежності.

Зважаючи на те, що до грудня 1991 р. Україна перебувала в колоніальній залежності від Росії (Російської імперії-Радянського Союзу), тобто мала статус колонії, то після проголошення незалежності вона стала постколоніальною державою, а суспільство - постколоніальним. Водночас, до такого типу країн застосовують і такі традиційні поняття, як «нові незалежні держави» та «транзитивні країни (суспільства)». Вже згадуваний В. Гьосле використовує також такі поняття як «країни, що розвиваються» та дещо застаріле - «країни третього світу». Щодо останнього, то він усвідомлює, що 3 розпадом Варшавського пакту поняття «третій світ» позбулося змісту, натомість «залишилося тільки два світи - світ багатих і світ бідних». Тому, на його думку, 
«нагальне питання найближчого часу полягатиме в тому, чи належатимуть східноєвропейські країни та колишні країни Радянського Союзу до першого чи до - все ще так званого - третього світу, який відповідно і мав би називатися «другим світом» [3, с. 145].

Застосування вищенаведених понять кардинально змінить ситуацію, оскільки дасть сучасній Україні чітку та прозору характеристику, відштовхуючись від якої можна будувати перспективні плани щодо модернізації українського суспільства, реформування військової сфери та формулювати відповіді на виклики, що постійно постають перед нашою державою протягом суверенного існування. Водночас відкриваються широкі можливості звертатися до суспільно-історичної практики нових незалежних держав (яких понад 100) з метою запозичення позитивного досвіду державного та військового будівництва та уникнення їхніх помилок на цьому шляху.

Як зазначалося вище, нові незалежні держави є складною реальністю, яка пов’язана з особливостями їхньої генези. Відтак постколоніальне суспільство це особливий тип суспільства. Воно фактично є антиподом «громадянського суспільства», яке виникло на певному етапі історичного розвитку західної цивілізації. Передумовами розвитку громадянського суспільства $є$ ринкова економіка 3 властивою їй багатоманітністю форм власності, множинність незалежних політичних сил та партій, недирективно сформована громадська думка і найголовніше - вільна особистість 3 розвиненим почуттям власної гідності [4, с. 79]. Крім того, громадянське суспільство - це не тільки емансиповане від держави суспільство, це ще й чітко структуроване суспільство.

У суспільствах нових незалежних держав перелічені вище якості відсутні взагалі або перебувають у зародковому стані. У цих країнах ухвалюються нові закони і конституції, отримують владу раніше заборонені організації, партії і рухи, встановлюються соціально-економічні та політичні правила поведінки тощо. Інакше кажучи, відбувається закріплення норм i вимог, які в майбутньому можуть стати засадами для створення демократичної правової держави. Суспільно-політичне життя в самостійній формі тільки налагоджується. Усе перебуває в процесі становлення, переходу, пошуків та змін.

Неструктурованість, наявність архаїчних нашарувань та інші вади, притаманні постколоніальним суспільствам, негативно позначаються на взаємодії соціальних інститутів із соціальним середовищем. Як відомо, підгрунтям взаємодії соціального інституту із соціальним середовищем $\epsilon$ реалізація головної функції соціального інституту - задоволення конкретних соціальних потреб. Проте соціально-політичні процеси в нових незалежних державах настільки динамічні, що нерідко виникає ситуація, коли швидкоплинні соціальні потреби не знаходять адекватної реакції у структурах та функціях відповідних соціальних інститутів, які, до речі, теж перебувають у стадії формування. Наслідками такої невідповідності в діяльності того чи того соціального інституту є так звані дисфункції. Ці явища проявляються i в 
зовнішній сфері - так би мовити, формальній (організаційній), і в самому змісті їхньої діяльності.

Ознаками зовнішніх дисфункцій соціальних інститутів постколоніальних держав $є$ брак підготовлених кадрів i матеріально-технічних засобів, організаційне безладдя тощо. Зі змістовного погляду, дисфункції соціальних інститутів таких країн проявляються в невизначеності мети та функцій їхнього існування, через що знижується їхній соціальний престиж i авторитет, піддається сумніву легітимність тощо.

Надзвичайно поширеним явищем соціальних інститутів постколоніальних країн є відсутність принципу деперсоналізації, який означає, що питома вага в забезпеченні функцій соціального інституту не залежить від суб'єктивних характеристик окремих осіб, які виконують покладені на них завдання. Втрата цього принципу призводить до того, що соціальний інститут перестає діяти відповідно до потреб суспільства та визначеної мети, змінюючи свої функції залежно від інтересів окремих осіб, їхніх персональних якостей і властивостей $[5$, c. 58$]$.

Поступово соціальний інститут дедалі менше орієнтується на досягнення основної мети свого існування - забезпечення конкретних соціальних потреб. Проте головне полягає в тому, що незадоволені соціальні потреби (як наслідок дисфункцій соціальних інститутів) викликають до життя нормативно неврегульовані різновиди діяльності, покликані компенсувати дисфункції легітимних інститутів, але вже за рахунок порушення існуючих соціальних норм (зокрема й правових). Наприклад, дисфункції окремих економічних та правоохоронних інститутів стимулюють такі поширені в постколоніальних країнах соціальні явища, як корупція, хабарництво, казнокрадство, клановість (сімейна чи регіональна), кумівство, протекціонізм за ознакою етнічного походження, конфесіональної належності, кровної спорідненості або земляцтва тощо.

Серед інших характеристик суспільно-політичного розвитку нових незалежних держав вирізняються такі: надзвичайно велика роль виконавчої влади; слабкість опозиції, яка зазвичай репрезентує інтереси усунутих від влади промислово-фінансових кланів; значна залежність партій, громадських організацій та профспілок від держави та бізнесу; відносна соціальна пасивність широких верств населення; відсутність або слабкість політичних організацій провідних прошарків суспільства; істотна роль окремих особистостей на ключових партійно-державних посадах; нерозвиненість електронних засобів масової інформації, зазвичай монополізованих панівною верхівкою та наближеними до неї скоробагатьками, капітал яких має переважно кримінальне походження; велика залежність держави від міжнародних фінансових організацій і колишньої метрополії тощо.

За таких умов домінуючою силою держави $є$ представники того прошарку, який має відносну автономію від усіх укладів, тобто бюрократія - цивільна та/або військова [6, с. 277]. 3 часом саме ця соціальна група, встановивши авторитарну владу, обмежує інтереси компрадорської буржуазії (олігархія), яка 
зацікавлена у створенні вигідної для неї системи представницької, парламентської демократії “західного типу”. Проте як свідчить суспільноісторична практика, те, що пустило коріння в розвинених країнах світу, не відразу приживається в постколоніальних державах, які переживають болісний процес первинного накопичення капіталу, політичної інституалізації та соціальної стратифікації. Демократичні процедури - і то не всі - можливі лише на певному етапі їхнього розвитку.

Незацікавленість у поступальному та систематичному розвитку вітчизняної економіки, розрахованому на довготривалу перспективу, прагнення «товкти гарячі гроші», жити одним днем за принципом «після нас хоч потоп» неминуче призводять до того, що починають переважати кон'юнктурні інтереси, виникає схильність «хитрувати» та уривати якнайшвидше i якнайбільше, що тільки можна й де тільки можна. Саме за таких умов в країнах, що розвиваються, відкриваються небачені можливості для зловживань, всюдисущої корупції, казнокрадства, хабарництва, протекціонізму тощо.

Згодом така поведінка переноситься з економічної сфери до політичної, що відтепер розглядається як найважливіший чинник легалізації, збереження та примноження статків, нажитих «непосильною працею», отримання різноманітних преференцій та імунітету від кримінальних переслідувань. Відбувається неприродне поєднання політики та бізнесу, межа між якими повністю стирається. За таких умов у постколоніальних країнах нерідко складається ситуація, за якої відсторонення від влади корумпованої верхівки, яка безсоромно підтасовує результати виборів, усуваючи у будь-який спосіб політичних конкурентів, демократичним шляхом практично неможливе, оскільки владна верхівка опанувала методи політичного шахрайства не менше, ніж фінансові махінації. 3 цього глухого кута можливі лише два виходи: або стихійні заворушення люмпенізованих прошарків суспільства 3 непередбачуваними наслідками, або військовий переворот, що є природним та логічним, а в більшості випадків навіть єдиним виходом 3 ситуації, що склалася.

У постколоніальних країнах, які виникають за умов відносно мирного («оксамитового») розпаду імперій, трансформація суспільств може відбуватися двома способами: стрибкоподібною, якісною зміною політичної системи, тобто за допомогою радикальних методів; або поступовим перетворенням колоніальної влади на національну під тиском зовнішніх та внутрішніх чинників.

Аналіз суспільно-політичної та соціально-економічної ситуації в Україні в контексті суспільно-історичного розвитку постколоніальних держав свідчить, що процес реальної модернізації українського суспільства невиправдано затягнувся [7]. Як зазначає М. Михальченко, програма ринкових перетворень в Україні протягом ii незалежного існування здійснювалася безсистемно та непослідовно. Концепція різкого, обвального послаблення ролі держави під час модернізації українського суспільства, звуження іiі лише до напрацювання «правил гри» виявилася помилковою [1. с. 138]. Усе це відбувалося на тлі 
боротьби регіональних, сімейно-кланових угруповань за доступ до контролю над матеріальними ресурсами, фінансовими потоками та держбюджетом загалом. Загострення зазначеної боротьби періодично призводило до клановоолігархічних переворотів, тобто насильницької зміни регіональних, сімейнокланових угруповань при владі, які зазвичай маскувалися під соціальні революції.

Найхарактернішою ж особливістю української влади з часу проголошення незалежності $\epsilon$ цілковита відсутність прагнення до реального оновлення. Проте саме здатність до оновлення, як вважає Ф. Фукуяма, є джерелом величі будьякої держави [8].

Ситуація невизначеності з формою державного правління означає лише одне - відсутність відпрацьованого механізму утримання та передачі влади панівною верхівкою, неврегульованість тї статусу і легітимності існування. Звідси й брак політичної волі до початку справжніх реформ та зволікання 3 будь-якими радикальними перетвореннями в усіх сферах українського суспільства [7]. І це відбувається навіть тепер, коли необхідно давати відповіді на небезпечні зовнішні та внутрішні виклики.

Внаслідок цього реальні кроки щодо модернізації українського суспільства підміняються їхньою імітацією, а то й взагалі дискредитуються соціальним популізмом, пов'язаним з перманентними виборами та бажанням за будь-яку ціну утриматися при владі. Як тут не згадати У. Черчилля, який вважав, що політик орієнтується на наступні вибори, а державний діяч - на наступні покоління. Вочевидь, що це більш ніж слушно стосовно нашої держави, де реальні перетворення, зважаючи на завершення третього десятиліття іiі незалежного існування, так і не розпочалися.

Зазначені чинники постійно генерують дисфункції соціальних інститутів українського суспільства, які ще більше поглиблюють соціальну кризу в державі. А це, у свою чергу, несе в собі потенційну загрозу соціальної дезорганізації, наслідком якої можуть бути або військово-політична інтервенція 3 метою запобігання соціальній катастрофі, або втрата політичного суверенітету ще над якоюсь частиною української території чи країною загалом.

Відомий український політик та економіст В. Суслов, характеризуючи українську державу протягом останніх десятиліть іï суверенного існування, зазначає, що «за Конституцією Україна - соціальна держава, а за реальною сутністю - кланово-олігархічна. Тому вся ця зворушлива турбота про багатіїв у нинішній системі влади невипадкова». «У нас є незалежні профспілки? запитує він і відповідає. - Нi, вони нічиїх прав не відстоюють. У нас є партії ідеологічного типу, засновані на обстоюванні певних ідей? Нi, у нас $є$ бізнеспартії. Незалежні суди, якщо й трапляються, то надзвичайно рідко. Ми поступово рухаємося до серйозного соціального потрясіння, соціальної відсічі знизу, яка практично неминуча, оскільки влада сама себе обмежити не в змозі» [9]. 
Висновки та перспективи подальших досліджень. Як свідчить проведений аналіз, внутрішні та зовнішні виклики і загрози, які постали перед Україною на сучасному етапі, повинні стати стимулом до формування адекватних відповідей. Зазначене потребує цілісної концепції модернізації усіх сфер життєдіяльності українського суспільства i передусім глибокого реформування освіти та науки в інтересах оборони. Реалізація цих вимог зумовлює зміст та спрямованість головних засад і першочергових завдань модернізації. Передусім реформування має здійснюватися одночасно в усіх сферах життєдіяльності українського суспільства. Серцевиною реформ повинна стати військова сфера, оскільки від перебігу російсько-української війни буде залежати майбутнє нашої держави, а тому це головне. Саме військова реформа (оновлена система військової освіти та комплектування, продумана конверсія військових кадрів, послідовне створення замкнутих циклів виробництва озброєння та військової техніки на власній промисловій базі тощо) має стати тим локомотивом, який сприятиме відродженню потужного обороннопромислового комплексу, а через нього відбудеться індустріалізація нашої держави. Водночас, внаслідок військової реформи повинна постати «нова модель Збройних Сил України», з'явитися нові підходи до російськоукраїнської війни загалом.

Інші сфери життєдіяльності українського суспільства теж вимагатимуть радикальних перетворень, зокрема у політичній сфері. 3 одного боку, необхідно поширювати реальну демократію на противагу псевдо- або квазідемократії, а 3 іншого - збільшувати централізацію, посилювати роль виконавчої влади 3 одночасним радикальним реформуванням законодавчої [10]. Зазначені перетворення вимагатимуть кардинального перегляду підходів до форми держави. Вочевидь, при цьому доведеться звернутися до поглядів В. Липинського щодо форми правління в Україні, викладених ним у своїх знаменитих «Листах до братів-хліборобів» [11].

Ці та інші радикальні заходи дозволять нашій державі сформувати адекватні відповіді на сучасні виклики та загрози, здобути перемогу над підступним ворогом i, зрештою, збудувати омріяну багатьма поколіннями борців за незалежність - Велику Україну. Зазначене потребує подальших наукових досліджень проблем, пов'язаних 3 модернізацією українського суспільства загалом і реформуванням освітнього та наукового простору України зокрема.

\section{ЛIТЕРАТУРА}

1. Михальченко Н. И. Украинское общество: трансформация, модернизация или лимитроф Европы? Киев : Институт социологии НАНУ, 2001. 440 с.

2. Костенко О. Антинаукова Україна. День. 2010. 10 грудня.

3. Гьосле В. Практична філософія в сучасному світі. Пер. 3 нім., примітки та післямова Анатолія Срмоленка. Київ : Лібра, 2003. 248 с.

4. Рябов С. Г. Політологічна теорія держави. Київ : Тандем, 1996. 240 с.

5. Чорний В. С. Словник-довідник основних понять та категорій 3 філософськометодологічних проблем військово-соціального управління. Київ : НАОУ, 2006. 112 с. 
6. Симония Н. А. Эволюция восточных обществ. Синтез традиционного и современного. Москва : Наука, 1984. 356 с.

7. Каспрук В. Хто є хто в Україні. Сучасний стан нашого суспільства в аналітичному розрізі // Час. 1997. 17 січня.

8. Фукуяма Ф. Нова епоха // День. 2008. 18 листопада.

9. Присяжнюк А. Виктор Суслов : «Украинские реформы - это пережитки сталинского менталитета»// Главред. 2011. 4 мая. URL : http:/glavred.info/archive/2011/ 05/04/0847500.html. - Назва з екрану.

10. Чорний В. С. Сучасне українське суспільство: виклики і відповіді. Social development \& Security. 2018. № 5 (7). C. 41-55. URL: https://paperssds.eu/index.php/JSPSDS/article/view/71/54.

11. Липинський В. Листи до братів-хліборобів // Історія філософії України. Хрестоматія : навч. посібник / упорядн. М. Ф. Тарасенко, М. Ю. Русин, А. К. Бичко та ін. Київ : Либідь, 1993. С. 456-465.

12. Чорний В. С. Особливості розвитку суспільства, або Спроба отримати відповідь на запитання: «Що ми модернізуємо?» // Віче. 2011. № 13. С. 26-30.

13. Чорна I. В. Дигіталізація як одна 3 тенденцій розвитку медіа галузі. Бібліотекознавство. Документознавство. Інформологія. № 1. 2014. С. 76-81.

14. Чорний В. С. Військова організація України : становлення та перспективи розвитку : монографія. Ніжин: ТОВ «Видавництво «Аспект-Поліграф», 2009. 368 с.

\section{REFERENCES}

1. Mykhalchenko N. Y. (2001). Ukraynskoe obshchestvo : transformatsyia, modernyzatsyia yly lymytrof Evropy? [Ukrainian Society: Transformation, Modernization or Europe's Limitrof?]. Kyiv, Institute of Sociology of NANU, 440. (in Ukrainian).

2. Kostenko O. (2010). Antynaukova Ukraina [Antiscientific Ukraine]. Newspaper Den. (in Ukrainian).

3. Hösle Vittorio. (1995). Praktische Philosophie in der modernen Welt. München, C.H. Beck, 216. (in Ukrainian)].

4. Riabov S. H. (1996). Politolohichna teoriia derzhavy [Political science theory of the state]. Kyiv, Tandem, 240/ (in Ukrainian).

5. Chorny V. S. (2006). Slovnyk-dovidnyk osnovnykh poniat ta katehorii z filosofskometodolohichnykh problem viiskovo-sotsialnoho upravlinnia [Dictionary-directory of basic concepts and categories of philosophical and methodological problems of military-social management]. Kyiv, NAOU, 112. (in Ukrainian).

6. Symonyia N. A. (1984). Evoliutsyia vostochnykh obshchestv. Syntez tradytsyonnoho y sovremennoho [The evolution of the eastern societies. Synthesis of traditional and modern]. Moscow, Nauka, 356. (in Russia).

7. Kaspruk V. (1997). Khto ye khto v Ukraini. Suchasnyi stan nashoho suspilstva v analitychnomu rozrizi [Who is who in Ukraine The current state of our society in analytical terms]. Chas. (in Ukrainian).

8. Fukuyama Francis (2008). Nova epokha [The new era]. Newspaper Den. (in Ukrainian).

9. Prysiazhniuk A. (2011). Vyktor Suslov: «Ukraynskye reformb - эto perezhytky stalynskoho mentalyteta» [Viktor Suslov: «Ukrainian reforms are relics of the Stalinist mentality»]. Glavred Magazine. Retrieved from http://glavred.info/archive/2011/ 05/04/084750-0.html. (in Russia).

10. Chornyi V. S. (2018) Suchasne ukrayins'ke suspil'stvo: vyklyky i vidpovidi [Modern Ukrainian society: challenges and answers]. Social development \& Security. 5(7), 41-55. DOI: http://doi.org/10.5281/zenodo.1469309. (in Ukrainian).

11. Lypynskyi V. (1993). Lysty do brativ-khliborobiv [Letters to brothers-farmers]. History of Philosophy of Ukraine. Textbook, Kyiv. Lybid, 456-465. (in Ukrainian). 
12. Chorny V. S. (2011). Osoblyvosti rozvytku suspilstva, abo Sproba otrymaty vidpovid na zapytannia: «Shcho my modernizuiemo?» [Features of the development of society, or Attempt to get an answer to the question: «What are we upgrading?»]. Viche Magazin, № 13, 26-30. ([in Ukrainian).

13. Chorna I. V. (2014). Dyhitalizatsiia yak odna $\mathrm{z}$ tendentsii rozvytku media haluzi [Digitization as one of the trends in the media industry]. Library Science. Documentation. Informology, 1, 76-81. (in Ukrainian).

14. Chorny V. S. (2009). Viiskova orhanizatsiia Ukrainy : stanovlennia ta perspektyvy rozvytku: monohrafiia [Military organization of Ukraine: formation and prospects of development: Monograph]. Nizhyn: Publishing House Aspekt-Polihraf, 368 p. (in Ukrainian).

\title{
PЕЗЮМЕ
}

\author{
Виталий Чёрный, \\ доктор философских наук, профессор \\ Национальный университет обороны Украины \\ имени Ивана Черняховского
}

\section{Роль науки в модернизации украинского общества}

Целью статьи является исследование сущности, генезиса и возможностей Украинь как нового независимого государства в современном глобализированном мире. Для этого применялись общенаучные и спещиальные методы исследования. Определено, что, на сегодня, наше государство находится в особом состоянии. Только правильно определив это состояние, мы сможем выйти на путь сочиального прогресса. Обосновывается, что без помоши научных исследований, сделать это практически невозможно. В статье уточнено содержание отдельных понятий, получили дальнейшее развитие взгляды относительно их применения в модернизационном процессе. Современная российско-украинская войнь и стремление Украины вступить в НАТО выдвигают новые требования к возможностям украинского общества. Это выдвигает требование дальнейших научных исследований, связанных с модернизацией украинского общества в иелом и реформированием образовательного и научного пространства Украины в частности.

Ключевые слова: новые независимые государства; украинское общество; модернизаџия; военная реформа; наука; наџиональная безопасность; российско-украинская война.

\section{SUMMARY}

Vitaliy Chornyi,

Doctor of Philosophy, Professor National Defence University of Ukraine named after Ivan Chernyahovskyi

\section{The role of science in the modernization of Ukrainian society}

Introduction. Modern Ukraine is experiencing a complex and responsible stage of its development. It is conditioned by the emergence of new threats and challenges to the national security of our country, which require resolute answers. In this context, science occupies an important place. It is obliged to clearly define the status of Ukrainian society, to substantiate the main directions of its modernization, which will promote social progress.

Purpose. Therefore, the purpose of the article is to determine the status of Ukrainian society, to clarify the content of a number of concepts concerning the newly independent states, to justify the ways and directions of modernization of Ukraine. 
Methods. The application of general scientific and special methods during the study of Ukraine is conditioned by the specifics of post-colonial states as a complex social phenomenon.

Results. We have found that after the achievement of political independence, the metropolitan traits (for Ukraine - Soviet, communist, socialist, totalitarian, etc.) cannot automatically move to the characteristics of the newly created countries. At the forefront should come signs that adequately reflect the status of the state, both before and after the proclamation of independence. Therefore, Ukraine is a typical post-colonial state.

Originality. The real status of Ukraine as a post-colonial state is determined for the first time in the national scientific tradition. Views on the genesis of post-colonial states have gained further development, drawing on the historical practice of Ukrainian state building. A number of concepts related to these states are specified.

Conclusion. It is proved that modern Ukraine needs a holistic concept of modernization of all spheres of society's life. First of all, it needs the deep reformation of education and science in the interests of defense. The core of reform should be the military sphere. As a result of military reform, a "new model of the Armed Forces of Ukraine" should appear; new approaches to the RussianUkrainian war should emerge. This requires further scientific research of problems related to the modernization of Ukrainian society in general and the reform of the educational and scientific space of Ukraine in particular.

Key words: science; post-colonial states; Ukrainian society; modernization; military reform; national security; Russian-Ukrainian war. 